\title{
TEPUNG TAPIOKA SEBAGAI PEREKAT DALAM PEMBUATAN ARANG BRIKET
}

\author{
Nuwa ${ }^{1)}$, Prihanika ${ }^{2)}$ \\ 1) Staf Pengajar Jurusan Kahutanan Fakultas Pertanian Universitas Palangka Raya \\ Email : nuwa61@ gmail.com; HP 08125093500 \\ ${ }^{2)}$ Staf Pengajar Fakultas Teknik Universitas Kristen Palangka Raya. \\ Email : prihanika83@gmail.com; HP 082155044483
}

\begin{abstract}
The use of wood as a fuel and energy source has been since the time of our ancestors first and until now still widely used mainly by rural communities, as well as people in Bukit Rawi for the middle class down. Bukit Rawi KWP group as a partner located in Bukit Rawi village amounted to 4 (four) people, group members are housewives and as rattan wicker craftsmen.

The science and technology applied to KWP (Kelompok Wanita Perajin) Bukit Rawi is introducing tapioca starch as adhesive material, and introducing briquette charcoal making technique as alternative fuel.

The introduction of science and technology to Bukit Rawi KWP provides new knowledge and is an additional business opportunity so they are very interested.
\end{abstract}

Key Word : Tapioca Flour, Charcoal Powder, Charcoal Briquettes

\begin{abstract}
ABSTRAK
Penggunaan kayu sebagai bahan bakar dan sumber energi sudah sejak jaman nenek moyang kita dulu dan sampai sekarang masih banyak digunakan terutama oleh masyarakat pedesaan, demikian juga masyarakat di Bukit Rawi untuk golongan menengah kebawah. Kelompok KWP Bukit Rawi sebagi mitra yang terletak desa Bukit Rawi berjumlah 4 (empat) orang, anggota kelompok adalah ibu rumah tangga dan sebagai perajin anyaman rotan.

Iptek yang diterapkan bagi KWP (Kelompok Wanita Perajin) Bukit Rawi adalah memperkenalkan tepung tapioka sebagai bahan perekat, dan memperkenalkan teknik pembuatan arang briket sebagai bahan bakar alternatif.

Pengenalan Iptek ini bagi KWP Bukit Rawi memberikan pengetahuan baru dan merupakan peluang usaha tambahan sehingga mereka sangat tertarik.
\end{abstract}

Kata Kunci : Tepung Tapioka, Arang serbuk, Briket Arang.

\section{PENDAHULUAN}

\section{Analisis Situasi}

Kayu sebagai bahan bakar adalah merupakan salah satu sumber energi yang digunakan, mempunyai sifat-sifat kurang menguntungkan antara lain heterogen, kadar air yang tinggi mengeluarkan banyak asap sehingga mengotori peralatan memasak, banyak abu dan nilai kalor kurang tinggi. Penggunaan kayu sebagai bahan bakar dan sumber energi sudah sejak jaman nenek 
moyang kita dulu dan sampai sekarang masih banyak digunakan terutama oleh masyarakat pedesaan, demikian juga masyarakat di Bukit Rawi untuk golongan menengah kebawah. Kelompok pengrajin KWP Bukit Rawi yang terletak desa Bukit Rawi berjumlah 4 (empat) orang, anggota kelompok umumnya ibu rumah tangga yang mempunyai pekerjaan sampingan sebagai perajin anyaman rotan.

Arang briket di masyarakat pedesaan umumnya kurang begitu dikenal karena produk arang briket sulit untuk mendapatkannya dan sebagian dari masyarakat tidak mengenal apa yang dimaksud dengan arang briket, karena hanya di kenal di daerah perkotaan. Arang briket merupakan salah satu sumber energi yang cukup tinggi guna memenuhi kebutuhan dalam jangka waktu yang akan datang, selain itu arang briket juga sebagai alternatif untuk mengatasi kebutuhan akan energi migas yang harganya terus menaik. Arang briket pada umumnya digunakan sebagai bahan energi rumah tangga seperti untuk tungku pembakaran, dalam industri-industri pengenceran logam dan lain-lain.

Arang briket adalah suatu bahan bakar yang dibuat dari bahan tertentu yang mudah terbakar dicampur dengan perekat kemudian dikempa, atau arang briket adalah perubahan bentuk arang sehingga mempunyai bentuk yang mudah untuk dibawa dan digunakan.

Tepung tapioka berasal dari umbi ketela pohon yang dibuat menjadi tepung, yang sering digunakan sebagai bahan untuk pembuatan kue-kue dan aneka masakan. Pemanfaatan tepung tapioka sebagai bahan perekat karena zat pati yang terdapat dalam bentuk karbohidrat pada umbi ketela pohon yang berfungsi sebagai cadangan makanan. Tapioka apabila dibuat sebagai perekat mempunyai daya rekat yang tinggi dibandingkan dengan tepung-tepung jenis lain.

\section{Permasalahan Mitra}

Permasalahan prioritas yang telah disepakati bersama mitra :

- KWP Bukit Rawi yang terletak di desa Bukit Rawi teridiri dari ibu rumah tangga dan perajin anyaman rotan in belum pernah mendapat pelatihan membuat arang briket dari instansi terkait, baik Disperindag, Dinas Pariwisata ataupun Depnaker.

- Belum mempunyai pengetahuan, kemampuan dan wawasan yang cukup luas untuk mengetahui dan memanfaatkan tepung tapioka sebagai perekat dalam pembuatan briket arang.

\section{Tujuan}

Tujuan kegiatan pengabdian pada masyarakat yaitu IbM adalah :

- Memperkenalkan secara luas tentang bagaimana cara-cara pembuatan bahan perekat dari tepung tapioka dan cara pembuatan arang briket khusus bagi KWP Bukit Rawi sebagai mitra.

- Tambahan penghasilan bagi mitra KWP Bukit Rawi apabila mampu membuat briket arang dengan menggunakan perekat tapioka.

\section{METODE PELAKSANAAN Waktu dan Tempat}

Pelaksanaan Iptek bagi Masyarakat ini adalah dilakukan bersama mitra KWP Bukit Rawi di Desa Bukit Rawi Kabupaten Kahayan Hilir Provinsi Kalimantan Tengah.pada bulan Oktober 2013.

\section{Sasaran Kegiataan}

- Bertambahnya pengetahuan dan ketrampilan ibu-ibu pengrajin yang bergabung dalam Kelompok KWP Bukit Rawi dalam hal penggunaan tepung tapioka sebagai perekat dan cara pembuatan briket arang.

- $\quad$ Mencipkan peluang usaha baru sebagai tambahan penghasilan. 


\section{Metode Kegiatan}

Mekanisme yang dilakukan dalam melaksanakan IbM ini adalah :

- $\quad$ Perencanaan dan persiapan :

Menentukan dan menyusun jadwal pertemuan bersama mitra dan menyiapkan alat

dan bahan yang di perlukan.

- Tindakan :

Berupa implementasi kegiatan-kegiatan yang dilakukan adalah penyampaian materi, kemudian dilanjutkan dengan praktek langsungdengan mitra tentang cara-cara mebuat perekat dari tepung tapioka dan mebuat briket arang.

\section{- $\quad$ Observasi dan Evaluasi}

\section{Solusi yang Ditawarkan}

Solusi yang ditawarkan Yaitu pelatihan dan sosialisasi tentang pembuatan tepung tapioka sebagai perekat dalam pembuatan arang briket. Dengan adanya pengetahuan tentang teknologi pembuatan arang briket ini dapat memberikan peluang usaha baru dan tambahan penghasilan selain sebagai perajin anyaman rotan.

\section{HASIL DAN PEMBAHASAN}

Kegiatan Program Iptek bagi Masyarakat(IbM) berupa Pemanfaatan Tepung Tapioka sebagai Perekat dalam Pembuatan Arang briket, meliputi beberapa tahap kegiatan yaitu :

\section{Persiapan}

Pada tahap ini adalah mempersiapkan bahan-bahan untuk kegiatan yaitu : Tepung Tapioka, arang kayu,air bersih. Kemudian menyiapkan alat-alat yaitu : alat hidrolik untuk mencetak briket arang, Lumpang untuk menumbuk arang mengjadi serbuk arang, ayakan untuk menyeragamkan butiran/serbuk arang, cetakan briket, kompor dan panci untuk memasak dan membuat perekat dari tepung tapioka. Sebagai tahap persiapan tim juga berkoordinasi dengan mitra K.W.P. yang terletak di Desa Bukit Rawi untuk menentukan jadwal pelaksanaan kegiatan.

\section{Pelaksanaan}

Setelah semua bahan dan alat-alat sudah siap dan mitra K.W.P. di bukit Rawi yang dilaksanakan pada tanggal 10-11 Oktober 2013. Adapun kegiatan yang dilaksanakan adalah :

- Penyiapan bahan dan alat untuk pembuatan arang briket dengan menggunakan perekat tapioka. Penumbukan arang agar diperoleh serbuk arang kemudian serbuk arang yang dihasilkan dari tumbukan kemudian diayak agar diperoleh butiran yang halus dan seragam agar perekat dapat merekat dengan sempurna.

- $\quad$ Tepung Tapioka kemudian dimasak dengan air agar menghasilkan perekat, kemudian campurkan perekat dengan serbuk arang sampai benar-benar tercampur rata.

- Kemudian campuran arang dan perekat yang sudah dicampur rata dimasukan dalam cetakan briket yang kemudian dipress dengan alat hidrolik.

- Briket arang yang dihasilkan kemudian dikering anginkan.

\section{Pendampingan}

Tahap pendampingan ini dilakukan untuk melihat sejauh mana mitra dapat mengaplikasi yang sudah dipelajari dalam kegiatan yang sudah dilaksanakan, dalam kegiatan ini juga dilakukan diskusi dengan mitra apakah mengalami hambatan atau kesukaran dalam melaksanakannya kembali.

\footnotetext{
Evaluasi dan Monitoring

Pada setiap akhir pelaksanaan kegiatan harus dilakukan evaluasi terhadap pelaksanaan kegiatan tersebut. Evaluasi bertujuan untuk memperoleh informasi
} 
tentang faktor pendukung dan penghambat dalam mencapai keberhasilan pelaksanaan program Ipteks bagi Masyarakat.

Evaluasi kegiatan dilakukan dengan membandingkan tujuan awal kegiatan yaitu Memperkenalkan secara luas tentang cara pembuatan bahan perekat dari tepung tapioka dan cara pembuatan arang briket. Melatih ibu-ibu rumah tangga untuk mampu memanfaatkan waktu luang dan menjadi pelaku usaha baru guna menambah penghasilan.

Faktor pendukung dalam kegiatan ini adalah sermangat para mitra untuk mengetahui tentang apa yang dimaksud dengan arang briket dan bagaimana tepung tapioka bisa dimanfaatkan sebagai perekat serta bagaimana proses pembuatan briket, sehingga sangat membantu para mitra dalam memahami, dan dapat melakukannya sendiri masing-masing untuk meningkatkan ketrampilan agar dapat menciptakan pekerjaan baru selain sebagai pengrajin.

Terlepas dari beberapa faktor pendukung di atas, terdapat beberapa faktor penghambat dalam pelaksanaan kegiatan IbM yang sudah dilaksanakan yaitu masih dihasilkan arang briket yang belum padat karena alat untuk mencetak briket sangat sederhana yaitu hirolik. Dalam proses pembuatannya memerlukan waktu yang lama serta untuk pemasarannya masih belum digalakan karena masyarakat lebih cenderung langsung menggunakan arang yang sudah jadi tanpa harus memproses lebih lanjut.

\section{DOKUMENTASI KEGIATAN}
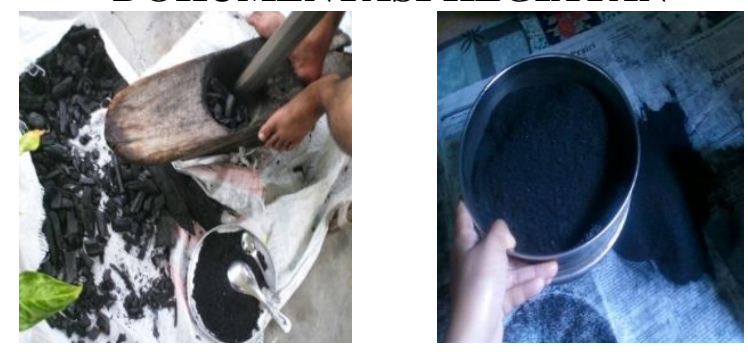
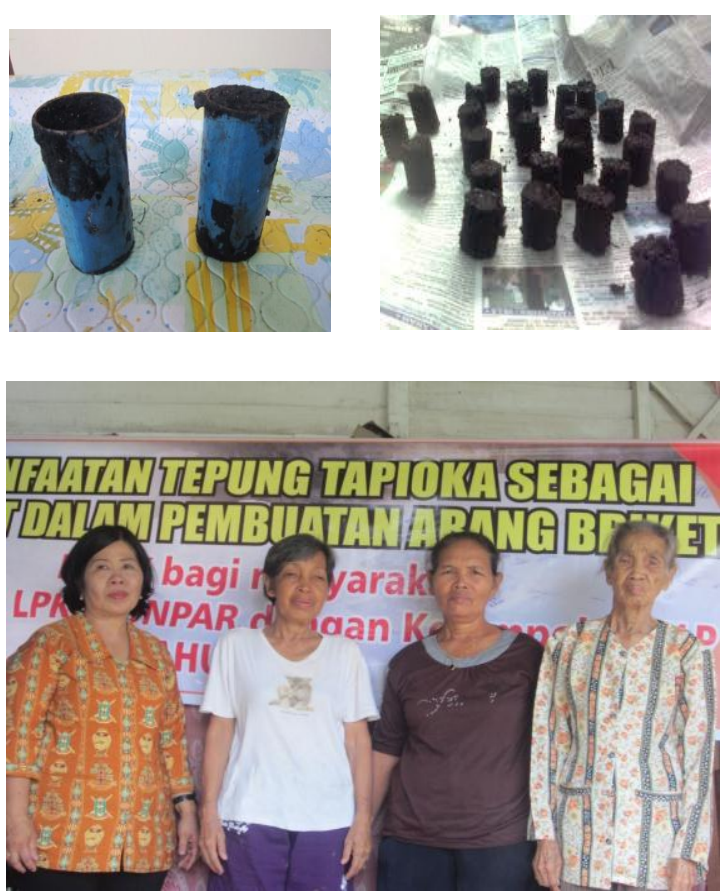

\section{SIMPULAN DAN SARAN Kesimpulan}

Kegiatan IbM tentang Pemanfaatan Tepung Tapioka Sebagai Perekat dalam Pembuatan Arang Briket berjalan dengan baik sesuai dengan jadwal yang sudah ditentukan. Mitra mampu mengikuti dan memahami berbagai tahap dalam kegiatan tersebut sehingga mereka memahami kegiatan yang dilaksanakan dan dapat membuat arang briket dengan memanfaatkan tepung tapioka sebagai perekat.

\section{Saran}

Untuk lebih meningkatkan kompetensi mitra, perlu dilakukan bimbingan yang terus menerus sehingga agar mitra menjadi mahir dalam pembuatan briket. 


\section{DAFTAR PUSTAKA}

Nuwa, 1987. Pengaruh Besarnya Pengempaan dan Ukuran Serbuk terhadap Kualitas Briket Arang dari Kayu Laban (Vitex pubescens JACK). Fakultas Kehutanan Universitas Lambung Mangkurat. Banjar Baru.

Pari, dkk. 1996. Kualitas Arang Aktif dari 5 Jenis Kayu. Buletin Penelitian Hasil Hutan. Bogor.

Pari Gustan, 2002. Teknologi Alternatif Pemanfaatan Limbah Industri Pengolahan
Kayu. Makalah Falsafah Sains Program Pasca Sarjana Institut Pertanian. Bogor. Patoni, dkk. 1995. Pemanfaatan Limbah Pertanian untuk Pembuatan Briket Arang dengan Campuran Batu Bara. Badan Penelitian dan Pengembangan Industri. Kalimantan Timur.

Prayitno, T.A. 1988. Perekatan Kayu. Yayasan Pembina Fakultas Kehutanan. Universitas Gadjah Mada. Yogyakarta. 